\author{
Савенко І.І. \\ доктор економічних наук, профресор \\ кафедра менеджменту та логістики \\ E-mail: IISavenko52@ukr.net \\ ORCID ID: 0000-0001-7901-6360 \\ Седікова I.O. \\ доктор економічних наук, профессор \\ кафедра менеджменту та логістики \\ Одеська національна академія харчових технологій \\ вул. Канатна, 112, м. Одеса, Україна, 65039 \\ E-mail: irina-sedikova@ukr.net \\ ORCID ID: 0000-0003-4376-1267
}

\title{
ДЕЦЕНТРАЛІЗАЦІЯ ВЛАДИ, ЯК ІННОВАЦІЙНИЙ ВЕКТОР ВДОСКОНАЛЕННЯ ПУБЛІЧНОГО УПРАВЛІННЯ В УКРАЇНІ
}

Вступ до Європейського співтовариства ставить задачу, щодо принципово якісних змін публічного управління та адміністрування в Україні. У даному досліджені здійснено аналіз інноваційної складової в системі публічного управління та адміністрування України. Дослідження проводилося на базі реформи з децентралізації влади, яка ґрунтується на створенні об'єднаних територіальних громад, зміни границь адміністративно-територіальних одиниць країни. Визначено місце України в Глобальному інноваційному рейтингу розвитку країн світу; досліджено інноваційні підходи щодо проведення реформи та розглянуто нормативно-правові, науково-методичні, кадрові та мотиваційні умови проведення реформи. Доведено, що основними проблемами щодо впровадження інновацій у вітчизняному державному та муніципальному управлінні $€$ дефіцит фрахівців зі спеціальності 281 «Публічне управління та адміністрування». Відсутнє належне науково-методичне забезпечення функціонування органів публічної влади; законодавча не урегульованість багатьох аспектів взаємодії органів різних рівнів створюють прецеденти спротиву інноваційних нововведень, як на рівні органів управління, еліти та суспільства.

Ключові слова: інновації, публічне управління та адміністрування, реформи, децентралізація, об'єднані територіальні громади, спротив.

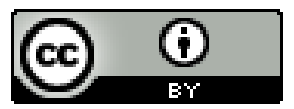

This work is licensed under a Creative Commons Attribution 4.0 International License http://creativecommons.org/licenses/by/4.0/
Постановка проблеми та її зв'язок з важливими науковими та практичними завданнями. Бажання України приєднатися до Європейського співтовариства, вимагає від держави імплементації власних законів, стандартів, актів, вимог в різних галузях національної економіки та сферах життя до європейських. Механізми функціонування економік Свропейського співтовариства та України повинні бути ідентичними. На сучасному етапі розвитку суспільних світових процесів інноваційний підхід є підгрунтям удосконалення сфери публічного управління та адміністрування (ПУА).

Аналіз останніх публікацій по проблемі. Інноваційний розвиток лідерів світової економіки забезпечується розвитком усіх сфер суспільства. Не виступає винятком і управлінська сфера. Перехід України від планової моделі функціонування до ринкової неможливий без встановлення нової системи публічного управління та адміністрування, заснованій на використанні передових інноваційних технологій. Тематиці інноваційної діяльності в органах публічно- го управління присвячені наукові розробки вітчизняних учених Афанасьєв М. В., Бакуменко В. Д., Дегтярьов І. О., Жаліло Я. А., Попов С. О., Романов В. В, Хачатурян Х. В., Шевченко О. В. та інших.

Формування цілей дослідження. Ціллю наукової статті виступає дослідження стану інноваційної складової в системі ПУА України. Для досягнення поставленої мети були вирішені наступні завдання: визначено місце України в Глобальному інноваційному рейтингу розвитку країн світу; здійснено класифікація інновацій в системі ПУА; досліджено інноваційні підходи щодо проведення реформи децентралізації влади в Україні та визначено умови нормативно-правового, науково-методичного, кадрового та мотиваційного характеру пов'язані з цим.

Виклад основних результатів та їх обгрунтування. У червні 2018 р. Корнельський університет, школа бізнесу INSEAD та Всесвітня організація інтелектуальної власності оприлюднили «Global Innovation Index 2018» розвитку 126 країн світу. Оцінювання інноваційного розвитку здійснювалося за 
допомогою рейтингу, який складався 380 індикаторів. Перше місце посіла Швейцарія 3 індексом 68,4 бали, подальші місця посіли Нідерланди, Швеція, Великобританія, Сінгапур, США, Фінляндія, Данія і Німеччина. Замикає десятку лідерів Ірландія 3 57,2 бали. Індекс України склав 39 балів, що дозволило потрапити в ТОП-50 країн [1].

У категорії «людський капітал і дослідження» (освіта, дослідницькі й академічні ресурси) Україна зайняла 43 місце, «витонченість бізнесу» (патенти, інтелектуальна власність, працевлаштування жінок і нацменшин, умови праці тощо) - 46 місце, «знання і технології» - 27 місце, «креативність» -45 місце [2].

Найнижчі показники Україна зайняла за параметрами «витонченість ринку» (кредити, інвестиції, конкуренція) - 89 місце, «інфраструктура» (доступ до урядових сервісів, вартість ресурсів, показники енергозбереження) - 89 місце, «інституції» (політична стабільність, ефективність влади, якість законів, суди і умови ведення бізнесу) - 107 місце [2]. Таким чином, у контексті вищевикладеного, виникає потреба у грунтовному дослідженні сучасного стану системи публічного управління та адміністрування в Україні, аналізі, вивченні та трансформування його на базі інноваційної складової. Можливості переходу в публічному управлінні на інноваційний вектор, вимагає наукового обгрунтування та поєднання категоріального змісту основних понять «публічне управління» та «інновація».

Класичний управлінський механізм представляє собою взаємопов'язані суб'єкт та об'єкт управління. Суб'єктами у публічному управлінні виступають: Президент України, органи законодавчої та судової влади, місцевого самоврядування, прокуратура інші органи державної влади, які не входять до системи органів виконавчої влади. Ключовим аспектом публічного управління виступає народ.

С. В. Ситник у статті «Мережева структура публічної політики та управління» визначає публічне управління як «...громадсько-мережева модель управління суспільством через зменшення ролі держави і збільшення кількості зацікавлених сторін» [3]. Науковці І. В. Луциків, О. А. Сороківська, І. В. Котовська вважають, що ПУА це «аполітична державна бюрократична структура, що функціонує в політичній системі й охоплює всі три гілки влади та взаємозв'язок між ними» [4].

Забезпечення інноваційного процесу здійснюється управлінською, науковою, проектною, організаційною, соціальною, інвестиційною, економічною та іншими видами діяльності. На рис. 1 наведено класифікацію сфер продукування інновацій в залежності від характеру.

Проведена класифікація дає змогу зробити висновок, що інновації в ПУА це новітні форми, підходи, механізми, технології роботи органів виконавчої влади, місцевого самоврядування, які застосовують задля досягнення поставлених цілей, удосконалення системи ПУА та забезпечення суспільного розвитку [5].
Критичний аналіз задач децентралізації влади в Україні дає змогу констатувати, що дана реформа за своїм змістом є радикальною інновацією. Основною ознакою даної інновації є кардинально нові методи та технології вирішення поставлених завдань, підгрунтям яких $є$ результати фундаментальних досліджень. Поява радикальних інновацій у ПУА пов'язана 3 новими адміністративними та регіональними (територіальними) реформами, з прийняттям нових прогресивних нормативно-правових та законодавчих актів, тобто в умовах посилення протиріч між суспільним та регіональним (територіальним) розвитком.

Наприклад, інноваціями в ПУА та муніципальному управлінні $є$ процес формування нових організаційних структур управління, фінансових важелів управління, розробка сучасних е-технологій управління суспільним і територіальним розвитком, механізми взаємодії органів публічної влади з суспільством та бізнесом тощо. Продукування означених інновацій потребує нових умов та забезпечення нормативно-правового, кадрового, науково-методичного, інформаційного, фінансового, мотиваційного характеpy.

Нормативно-правові умови, щзодо децентралізації влади. На початку реформування децентралізації влади (2014-2015 рр.) було прийнято низку Законів України («Про співробітництво територіальних громад», «Про добровільне об'єднання територіальних громад», «Про місцеві вибори»), Указів Президента України та Постанов Розпорядження КМУ тощо.

У Стратегії «Сталого розвитку «Україна 2020»»» наголошено «... що метою політики у сфері децентралізації $є$ відхід від централізованої моделі управління в державі, забезпечення спроможності місцевого самоврядування та побудова ефективної системи територіальної організації влади в Україні, реалізація у повній мірі положень Свропейської хартії місцевого самоврядування, принципів субсидіарності, повсюдності і фінансової самодостатності місцевого самоврядування» [7].

Законопроект «Про внесення змін до Конституції України щодо децентралізації влади» передбачає, що основою влади в Україні мають стати місцеві громади, які отримують значний об'єм повноважень, самі будуть збирати податки, формувати бюджети. «У власність територіальних громад передаються землі, рухоме і нерухоме майно, комунальні об'єкти, природні ресурси тощо. Замість обласних та районних адміністрацій держава буде представлена інститутом префектів» [8]. Законопроект визначає, що «...префект координує діяльність територіальних органів центральних органів виконавчої влади та здійснює нагляд за додержанням ними Конституції і законів України; забезпечує виконання державних програм; спрямовує і організовує діяльність територіальних органів, центральних органів виконавчої влади та забезпечує їх взаємодію з органами місцевого самоврядування в умовах воєнного або надзвичайного стану, надзвичайної екологічної ситуації. Глава держави зможе тимчасово призупиняти повноваження місцевих органів влади у випадку, якщо є загроза державному суверенітету» [9]. 


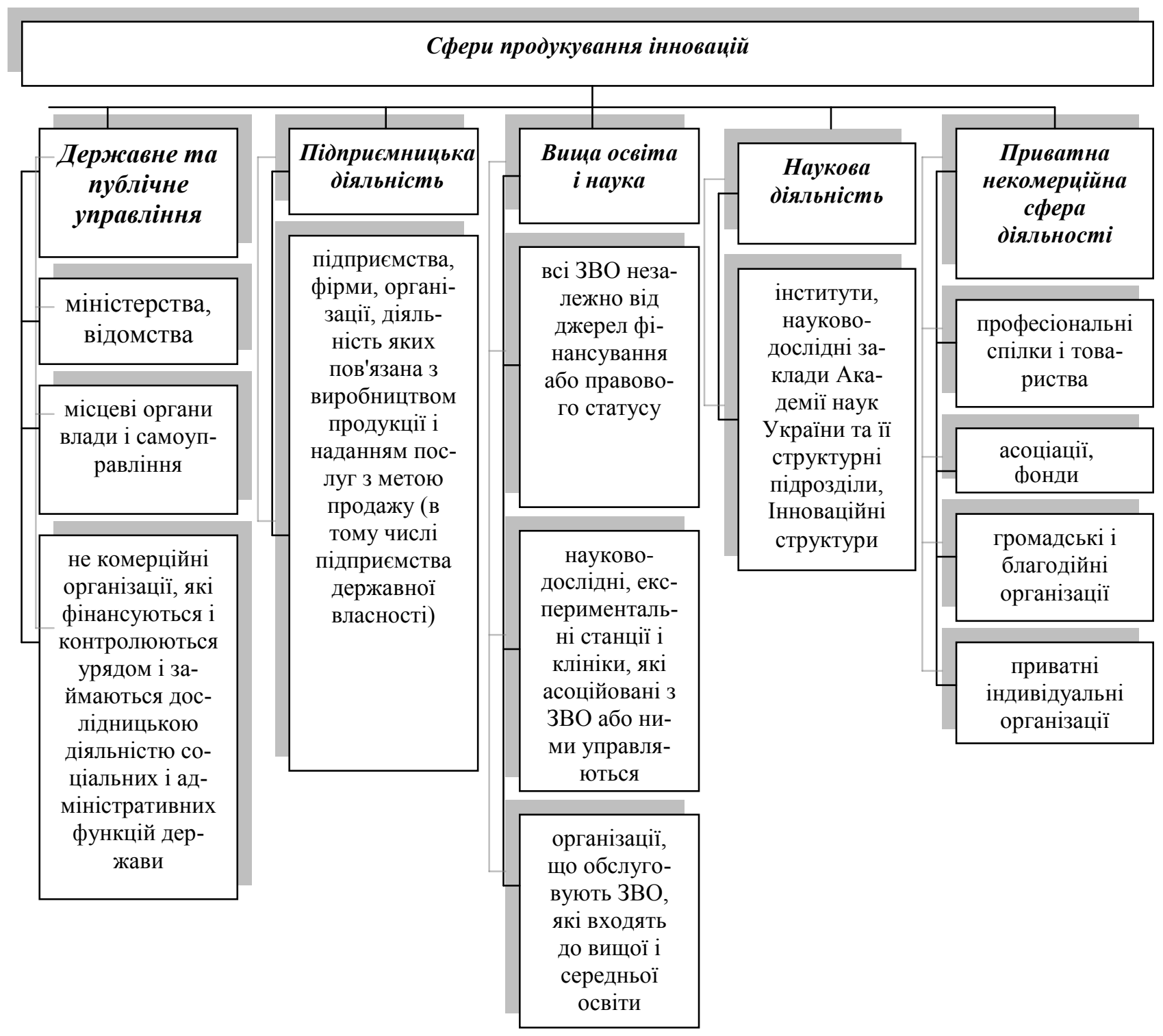

Рис. 1. Класифікація сфер продукування інновацій* *розроблено авторами

Кадрове забезпечення реформи. За інформацією Національного агентства України з питань державної служби, станом на 2016 р. в Україні налічувалося 351835 державних службовців та посадових осіб органів місцевого самоврядування, що становило 0,9 \% від загальної чисельності населення країни [10].

Скорочення чисельності посадових осіб органів місцевого самоврядування з 91925 до 83465 осіб (за 2005-2015 рр.) пов'язано з імплементацією реформи місцевого самоврядування. При цьому спостерігається збільшення кількості жінок на державній службі та на службі в органах місцевого самоврядування з 255513 осіб у 2005 році до 268419 осіб у 2015 році. Також спостерігається збільшення кількості осіб 3 вищою освітою - кількість державних службовців із 74,1 \% до 91,4 \% відповідно, кількість посадових осіб органів місцевого самоврядування із $62,5 \%$ до 75,4 \% відповідно [10].

Ситуація щодо професійної підготовки, перепідготовки та підвищення кваліфікації державних службовців і посадових осіб органів місцевого самоврядування в Україні знаходиться не належному piвні. У стандарті вищої освіти другого (магістерського) рівня вищої освіти галузі знань 28 «Публічне управління та адміністрування» визначено інтегральна, загальні та спеціальні компетентності, якими повинен володіти випускник даної спеціальності.

Інтегральна компетентність випускника сформульована, як «здатність розв'язувати складні задачі і проблеми у сфері публічного управління та адміністрування або у процесі навчання, що передбачає проведення досліджень та/або здійснення інновацій та характеризується невизначеністю умов і вимог» [11].

Загальні компетентності: «здатність генерувати нові ідеї й нестандартні підходи до їх реалізації (креативність), здатність здійснювати професійну діяльність і приймати обгрунтовані рішення, керуючись засадами соціальної відповідаль- 
ності, правових та етичних норм» [11].

Спеціальні компетентності: «...здатність організовувати та розробляти заходи щодо впровадження електронного урядування в різних сферах публічного управління та адміністрування; здатність визначати показники сталого розвитку на загальнодержавному, регіональному, місцевому та організаційному рівнях; здатність розробляти i впроваджувати інноваційні проекти на різних рівнях публічного управління та адміністрування...» [11]. Однак, як свідчить аналіз, тільки 0,58 \% державних службовців та 0,19 \% -муніципальних службовців володіють цими компетентностями. Отже, частка фахівців галузі управління для помітного збільшення його ефективності є досить малою і їі слід інтенсивно збільшувати. Відсутність стимулюючих факторів та відповідних умов щодо генерування та впровадження інновацій у вітчизняній системі ПУА, виступають перешкодою щодо застосування їх у практичній діяльності.

Умови науково-методичного характеру. Науково-методичне забезпечення діяльності органів публічної влади на сучасному етапі відчуває дефіцит інформації щодо існуючих світових практик з управління інноваціями. У європейських країнах координування інноваційних процесів втілюється в життя на основі розробки концептуальних новацій. Загальновизнаною $\epsilon$ концепція «good governance», яка об'єднує демократію 3 ефективністю управління в сучасних умовах е-суспільства і демонструє демократичний варіант державного менеджменту [12].

Поширеною концепцією управлінських інновацій як безперервного процесу вдосконалення у світовій і європейській практиці є модель KAIZEN. Ocновними концептуальними компонентами даної моделі є акцентування методологічного інструментарію на якісні показники, задля поступового розвитку та самовдосконалення системи державного управління; бездефектне управління (помилки, які виводять систему державного управління з рівноваги, зводяться до мінімуму); маркетинговий принцип орієнтації органів державного управління на потреби споживача. Х. В. Хачатурян у своїй роботі «Теоретико-методологічні засади інновацій у державному управлінні» відмічає, що «...у вітчизняній управлінській практиці, незважаючи на високу ефективність моделі KAIZEN як методології управлінських інновацій, вона майже не задіяна при розробці концепцій реформування державної служби та системи державного управління» [13].

Умови інформаційного, фінансового, мотиваційного характеру. Базою реформи децентралізації влади є створення об'єднаних територіальних громад (ОТГ). Для дослідження факторів спротиву нововведень при запровадженні реформ, слід виділити групи акторів, які проживають в ОТГ:

1. Жителі населених пунктів не пенсійного віку, мають земельні паї та передали їх в оренду. Інших офіційних доходів ця група населення не має.

2. Пенсіонери, які мають паї, передали їх в оренду. Отримують пенсії за віком.

3. Місцеві підприємці. Цю групу складають підприємці, що орендують землю у сельчан, місцевих рад і представляють найбільш професійно досвідчену частину населення (в минулому голови колгоспів, КСП, агрономи, бригадири - які мають аграрну освіту, мали доступ при розпаюванні та отримали техніку i створили власні господарства). На сьогодні виступають основними роботодавцями на селі.

4. Представники сільської інтелігенції, які згідно закону, отримали при розпаюванні по 2 га земель і продовжують працювати в соціальній сфері (закладах освіти, охорони здоров'я, відділень зв'язку, культури) або звільнилися і в дійсному часі не працюють або мають статус пенсіонера.

5. Молодь, яка на момент розпаювання не досягла повнолітнього віку, і в дійсний час немає земельних паїв, власного бізнесу, постійного робочого місця і фактично находиться на утриманні батьківпенсіонерів.

7. Представники місцевої влади - голови місцевих рад, старости, співробітники ОТГ, селищних рад, працівники правоохоронних органів.

8. Представники районних органів управління, які (органи управління) згідно із законом про децентралізацію влади підлягають реорганізації, ліквідації.

9. Представники обласних органів управління, які із певних інтересів впливають (мають можливість впливати) на зміну кордонів територіальноадміністративних одиниць, формування ОТГ.

Аналіз виділених груп за інтересами, можливостями, впливом на функціонування ОТГ дав змогу виокремити наступні види конфліктів.

1. Конфлікти щодо складу об'єднання. Громади населених пунктів за розвитком, матеріальним добробутом є різними - одні «багатші», інші «бідніші», що спричиняє спротив «багатих» громад до об'єднання

2. Конфлікти щодо розподілу ресурсів на розвиток та благоустрій інфраструктури населених пунктів ОТГ - доріг медичних установ, закладів освіти шкіл, дитсадків; будинків культури тощо.

4. Конфлікти за право розпоряджатися землями виробничого призначення (аграрного та промислового виробництва) у т.ч. поза межами населених пунктів та землями під приватні забудови, (розширення границь населених пунктів).

5. Конфлікти в середовищі місцевої еліти. Це конфлікти між головою громади і депутатським корпусом місцевої ради; між головою і старостою; гострі конфлікти між депутатами, які відображаються на всій громаді та ін. Ці конфлікти є найбільш гострими та небезпечними. Як провило депутатами $є$ місцеві підприємці, податки яких формують місцевий бюджет. Розподіл місцевого бюджету підприємці вважають здійснювати за власним сценарієм.

6. Конфлікти між владою ОТГ та району. Конфлікти викликані законодавчою неврегульованістю розподілу повноважень районних органів та органів управління територіальних громад. Двоякість співпраці 3 органами районних та обласних рівнів неминуче веде до виникнення конфліктів.

Зволікання з прийняттям законів урегулюван- 
ня відносин «суспільство - система управління» дає змогу управлінській еліті вважати себе ведучими акторами в суспільстві, а не найманими фахівцями для професійного ведення управлінського процесу.

Незважаючи на різноманіття мотивів, які лежать в основі виникнення конфліктів, основним фактором для більшості громад $є$ недостатнє кадрове забезпечення органів управління ОТГ; відсутність необхідного досвіду у посадових осіб місцевого самоврядування; недостатня інформованість представників місцевої влади щодо можливостей, які відкриває децентралізація та об'єднання громад.

Вивчаючи вітчизняний і зарубіжний досвід можна назвати основні перешкоди в ОТГ: слабкі мотиваційні можливості; не розуміння потреб в змінах та переваг від їх впровадження, відсутності конкуренції та механізмів, що сприяють зростанню ефективності діяльності; окремі цілі не піддаються вимірюванню, що спричиняє труднощі в оцінюванні ефективності тощо.

Окремим фактором спротиву нововведенням постає вплив ефекту освітньої гетерофільності публічних службовців. Освітня гетерофільність публічних службовців - це сукупність різнорідної освіти у середовищі публічних службовців, що, у свою чергу, формує належну інноваційну компетентність та інноваційну готовність публічних службовців щодо успішності впровадження нововведень. Цей фактор, зумовлений проявом неоднорідності освіти публічних службовців, яка уповільнює швидкість сприйняття ідеї інновації і цим стримує іï поширення у директивно визначений термін часу.
Інноваційна компетентність публічних службовців - це сукупність знань, вмінь і практичних навичок, способів мислення, професійних, світоглядних і громадянських якостей, морально-етичних цінностей, яка визначає здатність публічних службовців до успішного впровадження державно-управлінських нововведень [15].

Висновки та перспективи подальших досліджень. Вступ до Європейського співтовариства ставить задачу, щодо принципово якісних змін публічного управління та адміністрування в Україні, які зорієнтовані на потреби суспільства і громадян. Як показало дійсне дослідження та точки зору науковців 3 державного управління, основними проблемами щодо розробки і впровадження інновацій у вітчизняному державному та муніципальному управлінні $\epsilon$ дефіцит фахівців в органах державної виконавчої влади та органах місцевого самоврядування зі спеціальності 281 «Публічне управління та адміністрування»; відсутність науково-методичного забезпечення функціонування органів публічної влади та їх структурних підрозділів; відсутність мережі науководослідних організацій з продукування інноваційних проектів, їх впровадження, супроводу та ресурсноінформаційних центрів, лабораторій, бюро 3 акумулювання та поширення передового досвіду в публічному управлінні, функціонування об'єднаних територіальних громад, розбудови вертикалі влади: громада - округ - область - центр. Законодавча не урегульованість багатьох аспектів взаємодії органів різних рівнів створюють прецеденти спротиву інноваційних нововведень, як на рівні органів управління, еліт та суспільства.

\section{Література}

1. Україна у глобальному інноваційному індексі 2018 p // matrix-info. Одеса, 2020. URL: https://matrixinfo.com (дата звернення: 03.02.2020). 05.02.2020)

2. Epravda.com.ua: [інтернет-портал]. Одеса, 2020. URL: https://www.epravda.com.ua (дата звернення:

3. Ситник В. В. Мережева структура публічної політики та управління // Державне управління: удосконалення та розвиток. 2011. Т. 1, вип. 5. С. 25-31.

4. Луциків І. В., Сороківська О. А., Котовська І. В. Дослідження особливостей інноваційного розвитку системи публічного управління в Україні // Економіка і суспільство. 2017. Т. 5, вип. 12. С. 85-94.

5. Nuczu.edu.ua: [інтернет-портал]. Одеса, 2020. URL:

http://nuczu.edu.ua/sciencearchive/PublicAdministration/vol1/5-11.pdf (дата звернення: 05.02.2020).

6. Іноваційні підходи в управлінні регіональним розвитком : навч. посібник / за ред. Дегтярьова I. О. . Київ: Вид-во НАДУ, 2014. 318-322 с.

7. Про Стратегію сталого розвитку «Україна - 2020»: Указ Президента України. URL: // http://zakon0.rada.gov.ua/laws/show/5/2015. Київ: від 12 січня 2015 року № 5/2015, 2015. (дата звернення: 03.02.2020)

8. Про попереднє схвалення законопроекту про внесення змін до Конституції України щодо децентралізації влади: Постанова Верховної Ради України. URL: http://zakon4.rada.gov.ua/laws/show/656-19. Київ: від 31 серпня 2015 року № 656-VIII, 2015. (дата звернення: 03.02.2020)

9. Гладка Т. І. Децентралізація влади в Україні, як засіб посилення демократії та підвищення ії стабільності // Державне управління: удосконалення та розвиток. 2015. Т. 5, вип. 12. С. 28-37.

10. Аналіз ситуації щодо професійної підготовки, перепідготовки та підвищення кваліфікації державних службовців і посадових осіб органів місцевого самоврядування в Україні : інформаційно-аналітичний звіт. Київ: НАДУ, 2016. 58 с. (Державне управління). 
11. Стандарт вищої освіти рівень вищої освіти другий (магістерський) рівень галузь знань «28 Публічне управління та адміністрування» спеціальність «281 Публічне управління та адміністрування». Видання офіційне МОН України. Київ, 2019. 24 с.

12. Кондратюк А. П. Політичні тенденції модернізації державного управління країн Європейської співдружності // Вісник УАДУ. 2002. Т. 1, вип. 3. С. 209-297.

13. Хачатурян Х. В. Теоретико-методологічні засади інновацій у державному управлінні // ОРІДУ НАДУ. 2015. Т. 4, вип. 8. С. 35-44.

14. Жаліло Я. А., Шевченко О. В., Романова В. В. Децентралізація влади: порядок денний на середньострокову перспективу: монографія. Київ: Національний інститут стратегічних досліджень, 2019. 115 с.

15. Попов С. А. Державно-управлінські нововведення: теорія, методологія, практика: монографія. Київ: ОРІДУ НАДУ, 2014. 296 с.

Стаття надійшла 11.02.2020

Стаття прийнята до друку 25.02.2020

Доступно в мережі Internet 31.03.2020

\author{
Савенко И.И. \\ доктор экономических наук, профессор \\ кафредра менеджмента и логистики \\ E-mail: IISavenko52@ukr.net \\ ORCID ID: 0000-0001-7901-6360 \\ Седикова И.А. \\ доктор экономических наук, профессор \\ кафедра менеджмента и логистики \\ Одесская национальная академия пищевых технологий \\ ул. Канатная, 112, г. Одесса, Украина, 65039 \\ E-mail: irina-sedikova@ukr.net \\ ORCID ID: 0000-0003-4376-1267
}

\title{
ДЕЦЕНТРАЛИЗАЦИЯ ВЛАСТИ КАК ИННОВАЦИОННЫЙ ВЕКТОР СОВЕРШЕНСТВОВАНИЯ ПУБЛИЧНОГО УПРАВЛЕНИЯ В УКРАИНЕ
}

Стремление Украины присоединиться к Европейскому сообществу требует от государства адаптации собственных нормативно-правовых, законодательных актов и стандартов, всех жизненных сфер и национальной экономики к европейским. Механизмы функционирования экономики Европейского сообщества и Украины должны быть идентичны.

Присоединение к Европейскому сообществу ставит задачу принципиально качественных изменений в государственном управлении и администрировании в Украине. Активное инновационное развитие промышленности и экономики, происходящее на глобальном уровне, неизбежно вовлекало в этот процесс другие сферы общественной жизни. Проведенная классификация позволяет сделать вывод о том, что инновации в государственном управлении - это новейшие формы, подходы, механизмы, технологии работы органов исполнительной власти, местного самоуправления, использующиеся для достижения поставленных целей, совершенствования системы государственного управление и социального развития. Государственное управление в процессе постепенного реформирования все больше поглощает прогресс, достигнутый благодаря использованию инновационных технологий.

Исследование проведено на основе реформы децентрализации власти, основанной на создании единых территориальных сообществ, изменениях в границах административно-территориальных единиц страны. Определено место Украины в Глобальном инновационном рейтинге развития мировых стран; исследуются инновационные подходы к реформе децентрализации власти и рассматриваются нормативные, научные, методологические, кадровые и мотивационные условия рефрормирования. Доказано, что основными проблемами при внедрении инноваций на национальном государственном и муниципальном уровне управления являются нехватка специалистов по специальности 281 «Государственное управление и администрирование». Нет надлежащего научно-методического обеспечения функционирования органов государственной власти; нормативно-правовое регулирование многих аспектов взаимодействия органов на разных уровнях создает сопротивление внедрения инноваций, как на уровне правительства, элиты так и общества.

Ключевые слова: инновации, государственное управление и администрирование, управление, реформы, децентрализация, интегрированные территориальные сообщества. 


\author{
Savenko I. \\ Doctor of Economics, Professor \\ Department of Management and Logistics \\ E-mail: IISavenko52@ukr.net \\ ORCID ID: 0000-0001-7901-6360 \\ Sedikova I. \\ Doctor of Economics, Professor \\ Department of Management and Logistics \\ Odessa National Academy of Food Technologies \\ Kanatna str., 112 Odesa, Ukraine, 65039 \\ E-mail: irina-sedikova@ukr.net \\ ORCID ID: 0000-0003-4376-1267
}

\title{
DECENTRALIZATION OF POWER AS AN INNOVATIVE VECTOR FOR IMPROVING PUBLIC ADMINISTRATION IN UKRAINE
}

Ukraine's desire to join the European Community requires the state to implement and adapt its own laws, standards, legal and regulatory acts, requirements in various areas of the national economy and life spheres to the European ones. The mechanisms of functioning of the economies of the European Community and Ukraine should be identical.

The accession to the European Community sets the task of fundamentally qualitative changes in public administration and administration in Ukraine. The active innovative development of industry and economy, which is observed at the global level, inevitably involved other spheres of social life in this process. The conducted classification makes it possible to conclude that innovations in public administration are the latest forms, approaches, mechanisms, technologies of work of executive bodies, local self-government, which are used for achievement of the set goals, improvement of the system of public administration and social development. Public administration, without exception, in the process of gradual reformation is increasingly absorbing the progress made by resorting to the use of innovative technologies.

The study was based on a decentralization reform based on the creation of united territorial communities, changes in the boundaries of the country's administrative and territorial units. Ukraine's position in the Global Innovation Rating of the development of the countries of the world has been determined; innovative approaches to the reform of decentralization of power are explored and regulatory, scientific, methodological, personnel and motivational conditions of reforming are considered. It has been proved that the main problem with the implementation of innovations in the national state and municipal government is the shortage of specialists in the specialty 281 «Public administration and administration». There is no proper scientific and methodological support for the functioning of public authorities; the legislative regulation of many aspects of the interaction of bodies at different levels creates the precedent for resistance to innovative innovations, both at the level of government, elite and society.

Key words: innovation, public authority and administration, governance, reforms, decentralization, integrated territorial communities.

\section{References}

1. Ukraina u hlobalnomu innovatsiinomu indeksi 2018 r. (2020). Retrieved February 3, 2020, from https://matrix-info.com

2. Epravda.com.ua. (2020). Retrieved February 5, 2020, from https://www.epravda.com.ua

3. Sytnyk, V. V. (2011). Merezheva struktura publichnoi polityky ta upravlinnia. Derzhavne Upravlinnia: Udoskonalennia Ta Rozvytok, 1(5), 25-31.

4. Lutsykiv, I. V., Sorokivska, O. A., \& Kotovska, I. V. (2017). Doslidzhennia osoblyvostei innovatsiinoho rozvytku systemy publichnoho upravlinnia v Ukraini. Ekonomika i Suspilstvo, 5(12), 85-94.

5. Nuczu.edu.ua. (2020). Retrieved February 5, 2020, from http://nuczu.edu.ua/sciencearchive/PublicAdministration/vol1/5-11.pdf NADU.

6. Dehtiarova, I. O. (Ed.). (2014). Inovatsiini pidkhody v upravlinni rehionalnym rozvytkom. Kyiv: Vyd-vo

7. Pro Stratehiiu staloho rozvytku «Ukraina - 2020». (2015). Retrieved February 3, 2020, from http://zakon0.rada.gov.ua/laws/show/5/2015

8. Pro poperednie skhvalennia zakonoproektu pro vnesennia zmin do Konstytutsii Ukrainy shchodo detsentralizatsii vlady. (2015). Retrieved February 3, 2020, from http://zakon4.rada.gov.ua/laws/show/656-19 
9. Hladka, T. I. (2015). Detsentralizatsiia vlady v Ukraini, yak zasib posylennia demokratii ta pidvyshchennia yii stabilnosti. Derzhavne Upravlinnia: Udoskonalennia Ta Rozvytok, 5(12), 28-37.

10. NADU. (2016). Analiz sytuatsii shchodo profesiinoi pidhotovky, perepidhotovky ta pidvyshchennia kvalifikatsii derzhavnykh sluzhbovtsiv i posadovykh osib orhaniv mistsevoho samovriaduvannia v Ukraini (pp. 1-58). Kyiv.

11. Vydannia ofitsiine MON Ukrainy. (2019). Standart vyshchoi osvity riven vyshchoi osvity druhyi (mahisterskyi) riven haluz znan "28 Publichne upravlinnia ta administruvannia» spetsialnist «281 Publichne upravlinnia ta administruvannia». Kyiv.

12. Kondratiuk, A. P. (2002). Politychni tendentsii modernizatsii derzhavnoho upravlinnia krain Yevropeiskoi spivdruzhnosti. Visnyk UADU, 1(3), 209-297.

13. Khachaturian, Kh. V. (2015). Teoretyko-metodolohichni zasady innovatsii u derzhavnomu upravlinni. ORIDU NADU, 4(8), 35-44.

14. Zhalilo, Ya. A., Shevchenko, O. V., \& Romanova, V. V. (2019). Detsentralizatsiia vlady: poriadok dennyi na serednostrokovu perspektyvu. Kyiv: Natsionalnyi instytut stratehichnykh doslidzhen.

15. Popov, S. A. (2014). Derzhavno-upravlinski novovvedennia: teoriia, metodolohiia, praktyka. Kyiv: ORIDU NADU.

Received 11 February 2020

Approved 25 February 2020 Available in Internet 31.03.20

Цитування згідно ДСТУ 8302:2015

Савенко I.I., Седікова I.О. Децентралізація влади, як інноваційний вектор вдосконалення публічного управління в Україні // Економіка харчової промисловості. 2020. Т.12, вип. 1. С. 101-108. doi: 10.15673/fie.v12i1.1674

Cite as APA style citation

Savenko, I., \& Sedikova, I. (2020). Decentralization of power as an innovative vector for improving public administration in Ukraine. Food Industry Economics, 12(1), 101-108. doi: 10.15673/fie.v12i1.1674 